\title{
EU-topia? A critique of the European Union as a model
}

\author{
Tobias Lenz (tobias.lenz@giga-hamburg.de) \\ GIGA German Institute of Global and Area Studies, Hamburg, Germany \\ Kalypso Nicolaïdis (kalypso.nicolaidis@politics.ox.ac.uk) \\ University of Oxford, United Kingdom
}

The paper critically appraises the idea, both descriptively and normatively, that the European Union (EU) system can and should serve as a model for governance beyond its own borders. Engaging the postcolonial literature, it proposes a critical analysis of the idea, discourse and practice of Europe-as-a-model. We argue for a problematization of the label "model" without denying the value added by EU governance for the rest of the world. We start by developing an analytical heuristic that builds on three semantic meanings of the term model and outline the challenges of interpretation and translation that are associated with each. We then discuss these challenges along the Hegelian three-step of the model idea (thesis), its postcolonial antithesis and our constructive critique that seeks to steer a middle ground. We advocate greater reflexivity on the part of Europeans, that is, to systematically question assumptions behind their discourse and practice. If the cosmopolitan promise is to be retrieved from the radical critique of Eurocentricism, Europeans need to infuse the EU's message and practice with an ethos of mutual recognition as a crucial feature of a post-colonial agenda for the EU's role in the world.

Keywords: European Union, EU as a model, Governance, Critique, Postcolonialism

Our European model of integration is the most developed in the world. Imperfect though it still is, it nevertheless works on a continental scale ... and I believe we can make a convincing case that it would also work globally.

- Romano Prodi, former President of the European Commission

\section{Introduction: Do as the Romans do ${ }^{1}$}

The inside and the outside are two sides of the same coin, not only in the European Union (EU). ${ }^{2}$ This special issue is mainly concerned with the critique of internal practices and discourses, but the recent crisis makes it harder than ever to ignore their intimate link. The "migration crisis", which has triggered a new current of anti-EU sentiments exploited by right-wing populist parties in many EU countries, has roots in the EU's trade policy with

\footnotetext{
${ }^{1}$ This article has benefitted from countless discussions over the last few years. We would like to thank in particular our collaborators Nora Fisher Onar, Berny Sebe and Juri Viehoff.

2 Throughout, the article employs the term 'European Union' except in an explicitly historical narrative (pre-Maastricht) where the term 'European Community' (EC) might be used.
} 
Africa (for critical takes on EU trade policy with Africa, see Hansen \& Jonsson, 2015; Langan, 2016, 2018; and Weinhardt \& Moerland, 2018; on EU migration policy, see Buckel, Kannankulam, Wissel, \& Georgi, 2017). Similarly, the Euro crisis and Brexit both have profound repercussions for the EU's image beyond its borders.

Our contribution to this special issue thus turns towards this internal-external nexus: we draw on post-colonial and related critical theory in order to take stock of and criticize the discourses and practices associated with the EU as a model beyond its own borders - in short, the EU as a new Rome, a beacon for transnational governance. The story is this: from many corners of the globe, Brussels was proclaimed in the 1990 s and early 2000 s as the new lighthouse of civilised relations between countries. To be sure, the 2005 constitutional fiasco, followed by a financial crisis that engulfed world capitalism and tested European resilience to its limits, and now Brexit, have dented this narrative. But even as it struggles through this critical juncture, the EU continues to see itself as a reference point in the search for ways of managing problems that transcend national borders and, more idealistically, in the search for grounds to believe in the possible transformation of world politics. According to its own perception and narrative, this is a post-modern Rome or "benign civilizer" which does not seek to wield its power to coerce others and is not bent on imposing its rules, norms or values through conquest and domination but committed to spreading them through inspiration and persuasion. And therefore, 'do as the Europeans do' ought to be our motto ... when in Europe, or when elsewhere.

As authors and as European citizens, we have long been fascinated and baffled, proud and embarrassed, wry and confused about this story. What should we think about the idea and practice of 'Europe as a model'? Is it basically sound or intrinsically flawed? Does selling our model outside our borders amount to neo-imperialism? In this contribution, we do not reject what we call "model talk" altogether, but offer a method that draws on Hegel's dialectics in order to parcel out the problematic from what can be salvaged in this modern exercise in projecting normative power. We seek both to give its due and to "deconstruct" the idea of Europe-as-a-model and, ultimately, to suggest ways for Europeans of rescuing the narrative through self-reflexive engagement with the assumptions and beliefs on which it rests. This approach follows earlier calls for reflexivity in EU foreign policy (see, for example, Diez, 2005; Nicolaïdis \& Howse, 2002; Nicolaïdis, 2015; more generally, see Linklater, 2005), but goes beyond them in offering a systematic framework for grounding a normative critique of the EU-as-a-model idea that centres on identifying its assumptions, tensions and inconsistencies along three analytical dimensions: interpretation, translation and action. Overall, our approach calls for putting power back at the heart of discourse and narrative. We write in the vein of authors such as Thomas Diez, who argue that the hegemonic lens is best suited to reinstating the critical purpose that a concept like normative power was supposed to have from the start (Diez, 2013; see also Diez, 1999).

We proceed in five sections. We start by dissecting the notion of model, both semantically and analytically, and using the resulting structure as a heuristic to identify key challenges associated with the idea of the EU-as-a-model (section 2). We then discuss these challenges along the three-step of thesis, antithesis and synthesis. Section 3 describes how European policy-makers and academics alike draw on the idea to tell a progressive narrative about Europe. Section 4 outlines the radical critique of this idea, which highlights the implications of member states' colonial histories for the EU. Section 5 formulates our own normative benchmark with a view to reconciling the potential inherent in the idea and its radical critique, and section 6 assesses the EU's model practices on that basis. We conclude with a short summary of our argument. 


\section{The idea of the "EU-as-a-Model": Meanings and challenges}

The term "model" can have three semantic meanings revolving respectively around representation, aspiration and inspiration. These meanings involve decreasing levels of unilateral emulation from the original source, and while each of them is implicated in the discourse and practice of the EU as a model, each meaning poses different challenges across the analytical realms of interpretation, translation and action. We summarize the main elements of our argument in Table 1.

Table 1. EU as a model: Heuristic framework

\begin{tabular}{|c|c|c|c|c|}
\hline Core meanings & Referent & & Challenges & \\
\hline & & Interpretation & Translation & Action \\
\hline $\begin{array}{l}\text { One } \\
\text { A representation } \\
\text { of something } \\
\text { meant to support } \\
\text { its reproduction } \\
\text { (architecture, en- } \\
\text { gineering) }\end{array}$ & $\begin{array}{l}\text { Features selected as es- } \\
\text { sential to the model it- } \\
\text { self (e.g. model of coop- } \\
\text { eration). }\end{array}$ & $\begin{array}{l}\text { Which EU and/or } \\
\text { national charac- } \\
\text { teristics are se- } \\
\text { lected as essential } \\
\text { features? }\end{array}$ & $\begin{array}{l}\text { How can some- } \\
\text { thing stay the } \\
\text { same while } \\
\text { changing in scale } \\
\text { and context? } \\
\text { Prototype; tem- } \\
\text { plate; blueprint; } \\
\text { copy }\end{array}$ & $\begin{array}{l}\text { How can the } \\
\text { EU model be } \\
\text { adopted? } \\
\text { Strategies of } \\
\text { Adoption }\end{array}$ \\
\hline $\begin{array}{l}\text { Two } \\
\text { An object of aspi- } \\
\text { ration, worthy of } \\
\text { imitation. } \\
\text { (psychology and } \\
\text { role models) }\end{array}$ & $\begin{array}{l}\text { Features which aspir- } \\
\text { ants wish to appropri- } \\
\text { ate for their particular } \\
\text { function (e.g. power, } \\
\text { effectiveness, legiti- } \\
\text { macy) }\end{array}$ & $\begin{array}{l}\text { What EU qualities } \\
\text { or functions do } \\
\text { outsiders value } \\
\text { even if they do } \\
\text { not correspond to } \\
\text { specific features? }\end{array}$ & $\begin{array}{l}\text { How can one } \\
\text { translate some- } \\
\text { thing exceptional } \\
\text { to a different } \\
\text { context? } \\
\text { Beacon; Van- } \\
\text { guard; labora- } \\
\text { tory, experiment, } \\
\text { microcosm }\end{array}$ & $\begin{array}{l}\text { How can the } \\
\text { EU model be } \\
\text { adapted? Strat- } \\
\text { egies of Adap- } \\
\text { tation }\end{array}$ \\
\hline $\begin{array}{l}\text { Three } \\
\text { That which serves } \\
\text { as an inspiration } \\
\text { and the object of } \\
\text { re-interpretation } \\
\text { (figurative art) }\end{array}$ & $\begin{array}{l}\text { Features which are } \\
\text { amenable to reinter- } \\
\text { pretation and can be } \\
\text { borrowed and consid- } \\
\text { ered in isolation } \\
\text { (e.g. a single part of the }\end{array}$ & $\begin{array}{l}\text { What specific EU } \\
\text { features or func- } \\
\text { tions do outsiders } \\
\text { value? }\end{array}$ & $\begin{array}{l}\text { How can one ex- } \\
\text { plicitly transform } \\
\text { and subvert the } \\
\text { original features? } \\
\text { Quarry, toolbox; } \\
\text { exemplar }\end{array}$ & $\begin{array}{l}\text { How can the } \\
\text { EU model be } \\
\text { appropriated? } \\
\text { Strategies of } \\
\text { Appropriation }\end{array}$ \\
\hline
\end{tabular}

Source: own elaboration

\subsection{Three meanings}

We can distinguish three meanings of the term "model" according to their core ontological features, the use of the term in everyday language, and the referent that is implied.

The first meaning of model refers to its essential character and can be defined as "something which accurately resembles or represents something else", or more precisely as "a three-dimensional representation of a person or thing or of a proposed structure, typically on a smaller scale than the original" (Compact Oxford English Dictionary, 1991). This understanding of model as a representation is most common in 'technical' disciplines such as architecture or engineering, where a model helps designers to capture the main characteristics of an object on a smaller scale, either by reproducing the object after the fact or by providing a model to be reproduced in the future (architect's model). It hinges on the existence of two different objects with a specific relationship between them: the central features of an original (past or future) are represented in the form of something different, the model. The model is an ideal type (see Weber, 1968), a simplification, a smaller, simpler, purer version of the 'true' or 'real' thing. As such, a model is always selective in what 
it represents. Its idea is to capture the main features of an original, not to replicate it in its entirety. The main challenge, from this perspective, is to select these main features.

In contrast, the second meaning directly concerns the functions, which the features of the model are fulfilling in the eyes of the outsiders. In this vein, the Oxford English Dictionary defines model as "a person or thing eminently worthy of imitation; a perfect exemplar of some specified quality." We are interested here in how a model is used, that is, its relationship with its 'viewers', 'admirers' or 'clients'. This meaning is often used in psychology, when scholars try to understand human motivation. If something is considered worthy of imitation, or viewed as a 'role model', this is because it is perceived to possess some qualities that others of the same class do not. In essence, a model in this sense is something that one generally ought to aspire to, an apex in a hierarchy among units involving normative choices. Yet it also entails the subtext that a model in this sense can never be fully reached; it always remains in important ways "out of reach", or unique. From this perspective then, the main challenge for an admirer is to make the model suit his/her own circumstances.

The third meaning of model involves inspiration and interpretation, but like "a person employed to pose for an artist, photographer, or sculptor" (Compact Oxford English Dictionary, 1991), the model is only a starting point for its interpreter to follow her or his own design. This meaning is employed in the figurative arts, when an artist does not reproduce the model but interprets it to fit a vision, which is her own reality. She is inspired by specific features of the model and interprets them according to her vision of the final product. Such appropriation entails that the model may not be recognizable any more in the final product. Here, the main challenge is to decide which aspects of the model to interpret and how to interpret them.

\subsection{Three analytical realms}

These three meanings point to different challenges to the EU-as-a-model idea across three analytical realms: interpretation, translation and action. Interpretation refers to the question of how actors make sense of the EU model, how they understand its main features at the "source". Translation concerns the question of how actors may transfer the EU model, thus understood, to a different context. And action involves the question, for both the EU and its counterparts, of how to implement (or refrain from implementing) the idea of the EU-as-a-model by adopting, adapting and appropriating it.

Interpretation. Constructing a model involves interpreting the original object and considering the purposes of such interpretations for different actors. What are the original's main features? Which of its elements are essential, such that the original would not be recognizable without them? Often seen as a merely technical exercise, processes of interpretation entail a subjective element that reflects certain interests and dispositions. Poststructuralism teaches us that such processes involve struggles over contending interpretations of an object, which are infused with power, values and interests (Campbell, 2016; Walker, 1993). So when European policy-makers or academics refer to the 'EU model', they never talk about the EU as is, i.e. the 'original', but about a representation of it as they perceive the EU or deem its representation strategically advantageous. As Diez $(1999,603)$ puts it succinctly, "The power of discourse is that it structures our conceptualization of European governance to some extent, rather than us simply employing a certain language to further our cause." More importantly, the depiction of Europe as a 'model' involves struggles over competing interpretations of the model whereby even inconsistencies may not undermine, but be part and parcel of normative power (Diez, 2013). Hence, the way in which the 
EU is represented as a model tells us something about the interests and beliefs of those who refer to the Union in this way. ${ }^{3}$ What the EU model is depends on who is doing the interpreting.

In this vein, the most evident challenge in 'model talk' lies with the range of referents at hand, the plurality of potential essential characteristics. There is no consensus, and much potential dissensus, about what constitutes an accurate representation of the EU. 'Model' may refer to EU policies, concrete institutions or decision-making methods, or to what is claimed as specific European understandings of more general notions. The EU has been called a model of trade liberalization and competition policy; a model of supranational adjudication in the form of the European Court of Justice; of supranational democracy epitomized by the European Parliament or of well-balanced supranational decision-making as embodied in its finely weighted system of qualified majority voting; and even a "model of international cooperation in science, technology and sustainable development" (Stein \& Ahmed, 2007; see also Zaleski \& Mittermay, 2009; Laffan, 1998; Farrell, 2005; Jones, 2006). The EU may also serve as a stand-in for its main "constitutive values and principles" such as sustainable peace, social liberty, and inclusive equality. And more broadly still, the EU is often seen as representing a particular model of pooled or limited sovereignty - what Keohane $(2002,749)$ calls "a model of co-operative mutual interference."

But the idea of the EU as a model is more fundamentally plural in another way. That is when it refers not to the EU itself as a supranational institution but to features that the various national communities have in common, a range of national "models" honed within member states as self-contained but connected polities. In this case, we should speak of European models - such the social model(s), model(s) of capitalism, model(s) of democracy, legal model(s), model(s) of social integration - but in the EU model discourse these get aggregated somehow into some essence of a European model, as when Romano Prodi (2000) claims that "our social model can be a shining example to others." Indeed, there may be a fundamental tension between the idea of model embedded in the polities which compose the EU and the idea of model applied to the EU itself as the EU often works through inversing national realities. So, for instance, when the legacy of a majority of member states is monolingualism, the EU is a model of multilingualism. In this latter case, an individual member state (e.g. Belgium) can be selected as a "model" for the EU model.

Ultimately, problems of interpretation run deeper than the mere diversity of referents e.g. what does the model refer back to? The very way in which we can characterise the EU as a whole or its components is both contested and in flux. Hence, to ask about the "EU model" is to produce a range of interpretations or readings that may themselves change over time even on their own terms. The "EU model" that is to be projected does not exist in an even more fundamental sense. Instead, that which is projected is what actors conceive to be internal EU norms, institutions and practices rather than some objective reality. At one level, this is a trivial statement if we believe that social reality is always constructed (Wendt, 1999). But we mean this here also in a more literal sense, that is, that EU actors tend to "construct" an EUtopia which they then project on the outside. It is the EU as they would wish it to be that is to be projected, partly focussing on immanent "positive" features and underplaying other, less positive ones, partly by colouring interpretation with normatively informed prediction. And we as analysts are not exempt from this pathology of wishful projecting (Nicolaïdis \& Howse, 2002).

\footnotetext{
${ }^{3}$ Even though worthy of further study, we do not problematize here who the actors of such struggles are, be they EU officials or political actors in other parts of the world.
} 
These diverse interpretations and the contestation among them are most evident in the first meaning of model as representation where people argue over what is the "correct" representation of the EU. As we enter the more decentred realm of aspiration and finally vague inspiration, the question of interpretation becomes more subjective.

Translation. We must therefore ask about the exercise of translation between the EU model itself and what/whom it is supposed to serve. In the first meaning of model, translation is supposed to be as loyal as possible with the constraints of change in context. The challenge becomes greater and more central with the second semantic meaning of model where referring to the EU as a model does not call for slavish copying, but still means that it is not simply seen as one instance among many of a particular class of units, but as primus inter pares. European exceptionalism is inherent in model talk. Hence, whoever deploys the notion of the EU as a model, implicitly or explicitly, evokes this normative superiority by presenting its way of doing things as the one that is universally valid and (albeit not automatically) applicable to others (see Niranjana, 1992). Hence, in the most straightforward sense of regional integration, the starting point seems to be simply that as a formal project, it is older and deeper than others. But the claim is generally broader and entails the conviction that the EU represents a more 'civilised' mode of interaction between states. Only with the third connotation of the model idea do we open up the possibility that the model is only a useful toolbox among others from which the interpreter can pick and choose.

Obviously, the boundary between meanings Two and Three is porous. From a psychological perspective, even though imitating a model may enable someone to reach hitherto seemingly unreachable goals, such imitation always involves finding a form of imitation that is suitable to the imitating person's own characteristics and his/her distinct environment (Hartup \& Coates 1967). In this view, the term model involves "an image of imitation as an ongoing [process of] translation" that mixes copying and innovation in creative ways (Sévon, 1996, 51). How can one translate something exceptional to a different context? Conversely, how can one imitate something unique? And, more to the point, how can the EU model be relevant to others who do not accept the normative ordering inherent in this understanding of model? And how can it be potentially relevant to homothetic and heterothetic contexts?

Different semantic moves reflect different takes on these questions and the degree of external agency involved. At a most basic level, reference to an EU template or blueprint carries with it a connotation of reproduction with an emphasis on the technical dimension of the project. Talk of the EU as a beacon or a vanguard clearly contains the connotation of superiority, exceptionalism, or a city on a hill worthy of imitation as a role model. Referring to the $\mathrm{EU}$ as an example, presumably among others, amounts to toning down the rhetoric of superiority but not necessarily of asymmetry. The EU as a microcosmos of the global lead us to infer that there are differences in scale but not in the nature of the problems and contexts at hand between the EU and the global. As is the reference to laboratory or experiment, which suggests replicability - as well as fallibility and the sense that trials and errors in one context are relevant to the next. Alternatively, other terms suggest a more piecemeal and á la carte approach to translation as with the EU as quarry or toolbox. In the latter case, there is also an implication that the rest of the world can come and help itself, that the lessons are there for the taking rather than being actively sold outside of the EU. 
Indeed, the original model(s) always seems to be 'lost in translation'. The EU model will not be recognisable as such somewhere else, as a translation to other contexts can only be successful when it is internally consistent with the realities of these contexts. In this vein, EU actions pertaining to such export always risk falling prey to what has been called, in the context of the emulation of the EU model of integration, the "fallacy of transposition" (Langhammer \& Hiemenz, 1990; see also Lenz 2012).

Take the example of regional courts modelled on the European Court of Justice. Whereas the European Court of Justice is often seen as a success story in terms of ensuring compliance with EU law, other courts that have similar institutional designs have found it much harder to ensure a similar level of compliance due to differences in context. The Tribunal of the Southern African Development Community, for example, was entirely dismantled by member states after a controversial ruling over land reform in Zimbabwe (Cowell, 2013; see also Lenz, 2012), while the Andean Tribunal has survived by being much more reluctant to infringe upon member state sovereignty (Alter and Helfer, 2010). This example raises probing questions: How and to what degree is the 'EU model' flexible and adaptable enough to stay internally consistent when 'translated' elsewhere? If it was true that the $\mathrm{EU}$ is a 'Kantian island' operating in a world which does not share much of its assumptions - a 'Non-European world' - why should European recipes be translatable? And if on the other hand, the world does increasingly fit EU assumptions, why would the model even be necessary?

It may be that translatability hinges on choosing what is deemed translatable in the first place. Hence, when it comes to "exporting" the EU model, norms and institutions are as connected externally as they are internally: European norms or understandings do not float freely in the international governance universe but manifest themselves in concrete policies or institutions. Hence, the EU may try to export market legislation that directly springs from its own internal market model; or it can externalize the rule of law in a way that runs along the lines of internal understanding. In the first case, it runs the risk of overtranslation; in the second of under-translation.

Action. A third analytical realm is that of action or "model practices" to which we will turn in greater detail at the end of this article. Action here ultimately refers to what non-Europeans end up doing when confronted with an EU which we can situate somewhere on a passive to active spectrum - an asymmetric relationship ultimately defined by power asymmetries. In Table 1, we characterise the core questions related to action as how best to adopt, adapt and appropriate the EU model beyond Europe's borders. These questions refer to both sides, namely the EU and its counterparts, and to the ends (what) and means (how) that characterise them. We assess these questions through a normative benchmark - self-reflexivity and mutual recognition - that we develop as the synthesis of the potential inherent in the idea of "Europe-as-a-model" (thesis) and its radical critique (anti-thesis).

\section{An unfolding story: The cosmopolitan way?}

With the increasing assertion of the EU's external role in the first decade of this millennium, the idea of 'Europe as a model' for the rest of the world became highly fashionable in policy and academic circles alike (Khanna, 2008, chapter 2; Leonard, 2005). The term "Europe" generally tends to stand for the EU although part of the appeal of the model idea lies with the ambiguity. While the idea of "model" is generally associated with the passive, the painter's or engineer's object of translation from one medium to another, this story does not rest on opposing the EU-as-model and the EU-as-actor, but about Europe as an acting model. So, if with the term 'model', we refer to a set of European beliefs about the 
character of the EU itself and its relevance outside its borders, the overall policy agenda of "EU-as-model" generally refers to the set of practices enacted outside the Community's borders, which rest on such beliefs. While the existing literature on normative power Europe and EU foreign policy recognizes that internal EU policies and institutions often serve as the source of external practices (to name but a few important works, see Manners, 2002; Diez, 2005; Farrell, 2007; Sjursen, 2006; Lenz, 2013), a systematic characterization and normative assessment of this discourse and the associated practices under a single label are missing.

The Union, as the story goes, may seek to become a more prominent actor on the international stage, but not any old actor. With increasing explicitness its representatives have developed a powerful message: our actual or potential role in the world is not (only) about what we do, it is about who we are. The EU's own internal success may be seen as imperfect or a work in progress, but it nevertheless offers valuable lessons for the rest of the world. Romano Prodi (2000), former President of the European Commission, and quoted at the beginning of this piece, captures this mainstream mindset. In the last half-century, we have invented and fine-tuned a supranational system of governance, based on the values of freedom, human rights, the rule of law and democracy, which has brought peace and prosperity to a once war-torn continent. In this sense, the EU is a model that "provides a structure for the civilised resolution of global disputes and a civilised approach to the new global agenda", as former External Relations Commissioner Chris Patten (2003) notes. Is it not worth replicating such an achievement beyond our borders? The process we have followed can serve as a model for others: incrementalism built on a spillover logic, economic integration as a vehicle to achieve political ends, intergovernmental bargaining serviced by supranational institutions (Haas, 1958). Or in the words of David Miliband (2007), former British minister of foreign affairs:

"For the EU because nation-states, for all their continuing strengths, are too small to deal on their own with these big problems, but global governance is too weak. So the EU can be a pioneer and a leader. Our single market and the standards we set for it, the attractions of membership, and the legitimacy, diversity and political clout of 27 member states are big advantages. The EU will never be a superpower, but could be a model power of regional cooperation."

Whether as an object of slavish emulation or selective inspiration (according to the three meanings developed above), the EU's raison d'être on the international scene centres on the relevance of the être itself.

In the story, being and doing, which correspond to the internal and the external, are intrinsically linked. As Javier Solana explains: "In Europe we have learned the hard way that sustainable peace and security require regional cooperation and integration ... That is why supporting regional cooperation is such a 'growth area' in our efforts" (cited in Farrell, $2007,299)$. To be sure, "the model talk" is compatible with a range of practices on the part of the EU, from a passive blueprint or toolbox or quarry for others, to an active teacher, a preacher, a partner in shaping governance beyond the state. The EU's mission as a model is to "steadily reshape the nature of international politics and forge new mechanisms to manage interdependence and tackle cross-border problems" (Javier Solana cited in Farrell, $2007,299)$, its contribution to world order to invest in globalizing the kind of regional order it has created within. This is reflected, for example, in the European Social and Economic Committee's $(2006,124)$ insinuation that the European social model is a "global reference model...a source of ideas, experiences and inspiration for other countries or groups of countries." In practice, a number of concentric circles emanate from the core "model". 
Closest to home, the EU has helped conflate the process of state-building and memberstate building in Central and Eastern Europe and is seeking to do the same with countries and regions in its direct neighbourhood in South East Europe and across the Mediterranean (Bechev \& Nicolaidis, 2010; Bicchi, 2006). Further on, the Union is increasingly involved in teaching its lessons of regional integration to other actual or potential regions (Lenz, 2012; Lenz \& Burilkov, 2017). And at the global level, appeals to use the EU are supposed to inspire the creation, adaptation and reform of institutions ranging from the World Trade Organisation to the environment regimes to the G20 (Maur, 2005). In short, the promotion of the EU as a model has touched most dimensions of world politics in the past few years.

The turmoil and crisis ushered in by the global financial crisis of the late 2000s have not fundamentally altered this narrative. To be sure, the feebleness of the EU's response and capacity for adaptation have demonstrated once again the fallibility of the European project and the reversibility of an economic and monetary union considered as its core pillar. In the broader context of a world of rising powers, many of which have weathered the storm more effectively and are steadily outpacing the EU (Murphy, 2010; Roberts, Armijo \& Katada, 2017), this may have dented the credibility of the model story. But if anything, the story goes, the crisis demonstrates that the world is direly in need of supranational governance mechanisms for which the EU experience can provide useful pointers if not a wholesale blueprint. No one can deny that any ambitious project advances in fits and starts, advocates argue.

One of the striking dimensions of this story is the back-and-forth and mutual reinforcement between theory and policy. This is not a new story. Jean Monnet was convinced that the EC was not an end in itself but a means towards a better world (Monnet, 1978, 524) as was Alexandre Kojève (1973) when he wrote of the EC as the vanguard of the "end of history". The idea of Europe as a model for potential regional replica around the world has been around since the 1960s. Indeed, it is through these formative years that the discourse was forged, culminating in Duchêne's famous characterization of the EC as a 'civilian power' built "to domesticate relations between states", internally as well as externally (Duchêne, 1973, 19-20). Although Duchêne (1994, 408-409) later claimed that the EU "is not in any simple way a model", he still regarded it as the most innovative existing solution to the dilemma of international anarchy. When Ralf Dahrendorf, also a scholar turned diplomat, gave a series of speeches in Africa contemplating the prospects for a new world order (shortly after leaving his post in the European Commission in the mid-1970s), he still tagged a question mark to his 'Europe: A Model?' For him, especially given the wide failure of other attempts at regional cooperation in the late 1960s and early 19070s, the continued 'relevance' of European integration process was undeniable: "Thus it may be that there is something to learn from this story" (Dahrendorf, 1979, 37). This hesitance in the discourse largely had disappeared by the early 1990s following the transformations in the international system after the end of bipolarity and the Community's own deepening with the Treaty of Maastricht. By then, a number of analysts confidently called the EU a 'civilian model' in the spirit of Duchêne's original conceptualisation (Hill, 1990, 41).

The birth of the European Security and Defence Policy (ESDP) in 1999 unsurprisingly altered the perception of the EU as a civilian model. The EU was no longer contributing "to a different kind of international relations, in which civilian instruments are wielded on behalf of a collectivity which had renounced the use of force among its members and encouraged others to do the same" (Smith, 1998, 79). Nevertheless, the ESDP did not signal the end of the EU's civilian power image, but seems to have cemented it. How? Simply by 
emphasizing the (civilian) ends rather than the means of EU foreign policy. In this light, 'civilian' means non-state, not non-military (Forsberg, 2011). The EU is a civilian power in the international system as a result of its emphasis on multilateralism, mediation, trade and human rights.

In this spirit, the civilian power paradigm was 'upgraded' or, as some critics contend, 'relabelled' as normative power, that is the "ability to shape conceptions of normal" beyond its borders (Manners, 2002, 240). Robert Kagan's provocative quip about Europe as a Kantian island in a Hobbesian world may have been meant as a mockery of Europe's weakness but nevertheless told a powerful tale, in the wake of the Iraq war, of how "the transmission of the European miracle to the rest of the world has become Europe's new mission civilisatrice..." (Kagan, 2003, 61). And the flurry of responses which it provoked in turn led to further elaboration on the special features of the EU model (for example, see Nicolaïdis 2004). Indeed, some analysts could not resist an all-out defence of the EU as the only viable model, poised to "run the $21^{\text {st }}$ century" (Leonard, 2005; McCormick, 2007).

Most recently, the EU-as-model has made headway in the realm of international relations theory and more specifically normative theory and global ethics. The end of the cold war opened the way for mainstream IR scholars to increasingly question the (neo)realist vision of the immutable nature of international anarchy and power politics beyond the state, and to inquire about the transformative potential inherent in world politics. Building on the idea put forth by the English School of the potential for change from a "pluralist" to a "solidarist" international society of states, constructivists like Alex Wendt suggested that the European project could be seen as an incipient form of Kantian anarchy that could eventually characterise the global international system (in contrast, or combined with a Hobbesian or a Grotian system). Cosmopolitan writers followed in using the EU as an exemplar of the kind of cosmopolitan ethics called for at the global level. Since the wider world was "in need of more and better governance" it should take inspiration from the EU brand of 'civilizing process' (see also Beck \& Grande, 2007; Linklater, 2011). Jürgen Habermas expressed his admiration for the inherent potential of European integration as a model of 'post-national governance' including because he saw in Europe the kind of rational deliberative potential that alone could create the basis of a mature transnational political community (Habermas \& Derrida, 2003). And notwithstanding talk of a democratic deficit in the EU, its form of democracy beyond the state could be considered a forerunner of things to come in global politics (Bohman, 2013).

In sum, ever since the inception of the European integration process, and with increasing vigour in recent years, the question of whether and how the EU's experience is relevant to the wider world has been a theme in discourses mobilised both by European policy-makers and academics. Today, the EU is at a crossroads. It has spent half a century negotiating the transition to a non-European world, focused on surging from the ashes of its internal past. Having navigated this transition, its domestic experience is now increasingly invoked beyond its borders while the EU is becoming an actor in its own right. An ambition of benign influence through the upholding of its values by peaceful means and the selling of its genuine European brand of 'civil' relations between states to other relevant arenas of governance, be they national, regional or global. The mainstream has been largely uncritical in telling this story. But there is of course another side. 


\section{The radical critique as cautionary tale: Eurocentricism, EUniversalism and the politics of denial}

It is often said that the EU is grounded in the memory of the past and that the need to transcend such a past still constitutes the glue that binds Europeans together (Diez, 1994; Wæver, 1998). Here, the past that is invoked is the past of the civil-war-turned-world-wars which tore our continent apart 70 years ago. The EU, with its liberal and democratic ethos that eschews nationalist grandeur, stresses multilateral decision-making and cooperation in areas of 'low politics', is the direct counter-model to the prevailing form of 'intra-continental' politics during the 'European civil war' in the period between 1914 and 1945. The EU thus embodies the collective rejection of fascism, communism, exaggerated nationalism and militarism. In this well-known Europeanist account of the historical raison d'être of the European institutional model, other 'pasts' of European and non-European history are not normally included as relevant. This narrative may have been defensible as long as the EU was as a vehicle for the self-improvement and self-realization of Europeans, as it has been for most of the $20^{\text {th }}$ century.

But as the narrative of the European project turns from the exercise of internal (or intracontinental) self-realization towards global transformation, so should its memory frame. This is when 'other pasts' - both European and non-European - assert their relevance (Chakrabarty, 1992; Kleinfeld \& Nicolaïdis, 2009). When projecting the European model into a non-European world, i.e. demonstrating its relevance to non-Europeans with vastly different experiences and political structures, Europeans must confront aspects of their past that cannot be inserted as easily into the pre-war / post-war matrix of the original EU narrative. Foremost is the colonial experience, which structured Europe's interaction with the rest of the world from the beginning of the colonial era in the $17^{\text {th }}$ century to the end of official colonialism in the 1960s. It was European states that specified 'standards of civilization' - a set of liberal norms that defined criteria for membership in the international society of states - in the $19^{\text {th }}$ century and then set out to act as gatekeepers for such memberships, as the 'international society' in question originally started as the European continent (Bull \& Watson, 1982). And it was Europeans who sought to spread these norms through more or less violent imperial practices to other parts of the world until decolonisation, which coincided with the creation of a new Europe in the guise of the EU - notwithstanding the diversity of member states' pasts to which we will come back.

Thus, we need to start by understanding this clash of memories between the Eurocentric $20^{\text {th }}$ century memory of the great European wars turned world wars and the global memory of colonialism. Paying attention to alternative memory frames calls for a move away from Eurocentrism by appealing to the perception of others as well as by appealing to a re-reading of global history away from the western canons that have dominated the study of IR in general and European integration in particular.

So, a critique of "EU model talk" must start with an act of decentering memory itself as a first way of confronting the challenge posed by the vast post-colonial theory literature, itself reflecting and informing the widely held defiance of Eurocentrism in many parts of the world. In Nayak and Selbin's characterization of decentering, the expression denotes a state of "interrogating, disturbing, engaging, reframing, challenging, mocking, or even undoing mainstream, privileged ways of viewing the world" (Nayak \& Selbin, 2010, 8; see also Fisher Onar \& Nicolaïdis, 2013). In the eyes of all those around the world who still collectively "remember" Europe's colonial past from a non-European perspective, the EU's inward-looking narrative of self-improvement and vaccination against auto-aggression can be seen as a recycled, if more sophisticated, version of a bygone era. As Samir Amin (1989, 
166) explains, "Eurocentrism is not, properly speaking, a social theory, which integrates various elements into a global and coherent vision of society and history. It is rather a prejudice that distorts social theories." Engaging with the debate around Eurocentrism in the post-colonial literature helps us problematize some of the claims of the model talk, which has up to now largely escaped the scrutiny of post-colonial gaze. To be sure, accusations of neo-colonialism do not seem to have significantly dented the cosmopolitans' belief in the progressive and transformative promise carried by the EU in a re-invented version of its civilising mission (see Bhambra, 2016). Three deep features of the model talk explain why.

The construction of EUniversalism. A radical critique of the "model talk" must go back to the origins and understandings of universalism itself. The idea of the universal can depict anything that everyone recognizes and accepts as fundamental, indivisible and relevant to all human beings. In its most general acceptation, universalism then is a shared belief regarding the validity of a set of principles for all - starting with "the doctrine of universal salvation or redemption" (Compact Oxford English Dictionary, 1991). In its secular version, it is a "belief in the brotherhood of all men in a manner not subject to national allegiances." The Weberian definition describes universalism as "the insistence on treatment of all men by the same generalized, impersonal standards." But who does the 'sharing' in such a 'shared belief'? In contrast to the 'bird's eye view' version of universalism, the use of the term historically has served to name a particular discursive tradition originating in Europe and directed outside Europe. In short, universalism has historically been a project for the world as much as a vision of the world, from the late medieval, culturalist formulations of Christian fraternity to the rediscovery of classical Stoic thought during the Renaissance, and the dawn of secularism. As a project of a particular human community then, universalism has remained a discourse on the ability of one's community to define, embody, uphold, whatever it is that is deemed to be universal and the legitimacy of promoting it in the rest of the world. It is a claim about oneself as much as about the rest of the world. If, in Ruggie's (1982) formulation, hegemony is the fusing of power and purpose, a universalist discourse extends this logic by rooting the avowed purpose in the power of attraction rather than power tout court.

The politics of denial. But the EU has generally not been viewed as the specific incarnation of a consistent long-term universalist project. Instead, decolonisation was the handmaiden of a new "virgin birth" for Europe (Nicolaïdis, 2015). In reality of course, the EC was initially as much a product of colonisation, representing in the eyes of its founders a way to collectivise and pacify the colonial pasts of founding members such as France, Italy, Belgium and the Netherlands (Hansen and Jonsson, 2015). Paradoxically, and with decolonisation, the first decade of the EC's existence combined the rejection of Europe's presence in the world with the historical culmination of the internationalisation of the European society of nations: a world of sovereign states with territorial boundaries based on presumed homogenous nations which had 'earned the right' to remain sovereign. But just as Europe finally and unwittingly succeeded in shaping the world according to its own Westphalian image by retreating from it, a new Europe started to broadcast a new story about pooled sovereignty. As the idea of EU-as-a-model gained ground, a new narrative was invented for a decolonised world where the EC was supposed to be as much a newcomer as the newly independent states, a partner in development, which had nothing to do with its members' pasts. As former Development Commissioner told his African audience in the 1970s: "The Community is weak, it has no weapon... it is completely inept to exercise domination... The European Community is young, it has no past." (Claude Cheysson cited in Grilli, 1993, 102). In imagining the EU model as not-its-member states (reason against passion; 
supranationalism against nationalism) and as transcendence of those episodes in which Europeans have turned on each other, the history of Europe's colonial past has been erased from the official account - this was them, the EU is something else. As Hansen and Jonsson $(2014,446)$ aptly note, "Europe as an intergovernmental and supranational political project and entity has been placed outside and beyond the history of colonialism."

Atonement and Redemption. But of course, the story is not that simple. In the EU narrative, denial also gives way to the search for some kind of redemption. The EU becomes a means of atonement on behalf of its ex-colonial states, through special deals with ex-colonies and its development agenda. The denial lay in the continued assumption that the idea of a unilaterally defined mission could still be acceptable in the post-colonial world while the atonement lay in the attempted reinvention of European relations with the so-called third world in ways which genuinely serve the interests of the latter. Europe could do it again, export its ways and all, but get it right this time. Redemption lies with the idea that Europeans, manned with their unique insights into self-destruction and subsequent reconciliation and reconstruction, are in a position to help the rest of the world overcome the evils of nationalism and power politics - it seems fascinating that Europeans often do not see the ironic spirals involved in such reasoning (Nicolaïdis, 2015).

As a result of these discursive features of EUniversalism, the core tensions inherited from Europe's past - the tension between the two faces of European universalism - remained in a different guise. Is promoting the 'EU model' a late echo of conquest and domination, the imperial sense of mission, or a mark of transnational responsibility and cosmopolitan solidarity? To be sure, the discourse and practice of the EU-as-a-model could hardly be seen as a simple remake of the expansion of European 'international society' all over again in a world, which is no longer structured to allow for such Euro-centric expansion. But it does constitute a complex rewriting of the old story, with caveats and cautionary notes, bells, whistles, silences and all. And the question for us is whether and how such re-writing can be seen as legitimate.

\section{Our benchmark: Self-reflexivity and mutual recognition}

If there is no doubt that the legacy of Europe's imperial past resonates to this day in many corners of the globe, the question remains whether the EU can transcend Europe's past or rather the past of a number of its member states. What would it take for the EU to act as a genuine 'post-colonial' power in this realm, self-reflexive about the echoes of colonialism and legitimate in the eyes of other countries? How best can the EU live up to its postcolonial aspiration? Conversely, can we not argue that today's idea and practice of the EU as a model with its hands off and non-coercive character amounts to a toolbox for governance, which has precious little to do with the mission of yesteryear? Is it possible, in short, to avoid denying the EU's transformative promise while at the same time questioning its fundamental premise? We call for exploring these questions with an open mind. We reject the idea that one could or should be for or against Europe-as-a-model per se. But we are critical of the idea and practice as is. In particular, we are uncomfortable with the label "model" itself and prefer alternative ways to encapsulate the value added of EU governance for the rest of the world - alternatives which are more humble and convey a certain state of mind.

The state of mind we ourselves hope to share is simply one of reflexivity, that is the ability to reflect critically and openly upon both discourse and practice, the systematic questioning of the assumptions behind one's methods, and the capacity to draw lessons from outside one's world - whether from the past or from the perceptions of others. Andrew 
Linklater $(2005,144)$ has aptly described this state of mind as a normative perspective that is "less concerned with passing normative judgment on domestic practices elsewhere than with investigating the ways in which their own actions [and discourses] destroy, frustrate, demean or in other ways harm other peoples." Reflexivity here is called for both on behalf of "real world" actors and the world of Social Science - including in the ways in which these two worlds overlap. Some scholars have already pointed in this direction, from the "Eurocentric norms" and "paternalistic discourse about Africa" expressed in EU-Africa relations (Staeger, 2016, 981) or the finding of a "soft imperialism" inherent in the EU's interregional relations (Hettne \& Söderbaum, 2005) to a recasting of EU normative power as hegemony in order to reinstate the concept's critical purpose (Diez, 2013) and an analysis of the EU as an "imperial power" (Behr \& Stivachtis, 2016; Zielonka, 2008). But a comprehensive appraisal and critique is still needed (for a recent overview, see Hansen \& Jonsson 2018).

It may be that this self-centredness is due to the fact that the drive for EU external action is fundamentally internal - the balance of power, rivalries and turf games, which EU actors play among themselves (Bickerton, 2011). Nevertheless, we regard reflexivity as a normative ambition that European actors ought to aspire to in their foreign policy (see inter alia, Fisher Onar \& Nicolaïdis, 2013; Keukeleire \& Lecocq, 2018). If the EU's main hope for international relevance does lie in its ability to affect the definition of what is normal in international relations (Manners 2002), European policy-makers ought to engage in a constant process of reflection of what it is that they are advocating as 'normal', as if we could not see through what Spivak castigates as a strategic essentialism - e.g. "a strategic use of positivist essentialism in a scrupulously visible political interest" (Spivak, 1996, 214). Any depictions of the EU that may be seen as what Diez $(2005,636)$ has aptly described as "a self-righteous, messianistic project that claims to know what Europe is and what others should look like" needs to be eschewed. Conversely, the EU ought to avoid "utopian normativity" (Nicolaïdis \& Howse, 2002, 789) and embrace a genuine modesty about the claims of such practices. This may mean retaining very little of the EU-as-a-model practice. The simple transfer of EU institutions, policies and regulations to other parts of the world seems inadequate because the era of the civilising mission is over. Europe's continued relevance is at that price. Ex-ante, therefore, reflexivity calls for modesty about goals and means. Ex-post, it calls for the ability to honestly evaluate the effect and relevance of EU practices, including from a decentered perspective, admit policy failures and change course. But how can we tell?

Reflexivity can lead one to many conclusions, indeed many legitimate conclusions. Nevertheless, we ourselves wish to promote our own bias as we hope and believe that it can lead both practitioners and analysts to infuse the EU's message with greater legitimacy. This bias is an ethos of mutual recognition. Mutual recognition is about symmetry, reciprocity, partnership and mutual respect, indeed "mutuality" in the fullest sense. It means eschewing Eurocentricism, decentering both our practice of cooperation and our way of understanding the world. It means standing out of a European viewpoint and imagining the kind of world we would want to see even if Europe did not exist. Mutual recognition in this sense calls for Europeans to internalize the "post-colonial condition", that is, the awareness of the implications of their colonial past both in terms of structures - of the international political system and globalization - and in terms of echoes and perceptions; and it implies a willingness to resolutely and self-consciously move beyond colonial patterns - patterns recognised as such by others.

We do not naively deny the structural realities of today's global system, its fundamentally hierarchical nature and the asymmetries of power, which underlie contemporary inter- 
national relations, including in the EU's external relations. A relationship of "influence" involves by definition an element of inequality and hierarchy. But the discourse of the EUas-a-model is often grounded on a sense of superior normative or cognitive power, which Europeans somehow feel and believe continues to be their prerogative. This is where, we believe, self-reflexivity is in order. The question is to what extent it is possible to introduce more symmetry in the "model" narrative. Mutuality entails that EU model practices are not a one-way street, but that learning and development in the relationship is mutual. This includes the possibility that EU actors learn from the other side not just how the EU model may best be adapted to fit their context, but how the EU model itself may be enhanced based on their experience. Genuine mutuality, therefore, is the lesson to learn from the EU's colonial experience and its echoes, and it provides the basis for "levelling" the field of international politics that is still very much dominated by power asymmetries and status hierarchies between the EU and many of its partners.

\section{A constructive critique: Action in the light of self-reflexivity and mutuality}

Finally, we come back to the third realm within which the EU-as-a-model is deployed, the realm of action. It is when we reach the issue of action that the radical critique is most likely to bite. After all, laying out and seeking to translate a model can amount to cheap talk. The rest of the world is welcome to engage in the exercise - or not. What happens when the EU acts on it? The EU can export, spread, externalize, transpose, advance, push or impose its model. Less proactively, it can also simply present, exhibit, offer, suggest, advertise, glorify, parade or showcase it. All of these notions, extensively used before the EU's poly-crisis of the last decade, may have come to be used with more circumspection but they remain part of the EU repertoire. Which of them best captures the essence of the EU's model practices? And what practices are most legitimate, if any?

In practice, the EU model problématique stretches across the whole range of EU external relations that range from relations with individual countries via groups of countries and inter-regional relations with other regional organizations to the EU's actions in different arenas of global governance, such as the United Nations or the World Trade Organization. In all of these relations, the EU seeks to exercise "external governance" (Lavenex \& Schimmelfennig, 2010), that is, it attempts to transfer the EU model to various degrees to its partners. As one radiates outward from the EU's immediate neighbourhood towards more distant countries and regions, the EU's ability to leverage (accession) conditionality and its structural "power in and through trade" (see Meunier \& Nicolaïdis, 2006), and thus its ability to control outcomes, diminishes. Nevertheless, in all of these settings the logic of interaction is the same: the degree of convergence to European or otherwise "universal" norms and standards is a function of "the club" to which one belongs or is expected to belong; and states gain some measure of access to the EU (from its markets to financial support and ultimately to membership) as a quid pro quo for some degree of convergence with its standards. Thus, whereas changes in structural asymmetry affect the likelihood of particular outcomes, the normative question of how relevant actors can best adopt, adapt and appropriate the EU model remain similar. We discuss questions of content and agency in turn.

\subsection{The what question: Sensitivity vs. consistency}

Our take on the what question lies with consistency and its many facets. Most basically, people ask, is action consistent with discourse? Of course, neither the EU nor most political actors, nor indeed most of us can live up to the standards of our discourse. Our concern with consistency is more specific to the model problèmatique and refers to the "consistency between the internal and external planes" of EU activism (Nicolaïdis \& Howse, 
$2002,771)$. To be considered credible by others, actors not only ought to act upon what they preach abroad but, more importantly, ought to do abroad what they themselves are doing 'at home'. From this perspective, it is problematic, for example, for the EU to ask other actors to engage in 'open regionalism' that does not discriminate against outsiders shortly after the founding of a regional grouping when European integration itself was based on sustained protectionism for most of its first four decades. This challenge refers to potential gaps between the actual model the European member states have constructed at home and the practices they seek to export. It raises a number of crucial questions: does the EU act in ways, or demands from others to act in ways, that are consistent with the way in which European states organize their joint affairs inside Europe? In other words, how authentic are EU model practices? And, conversely, does it practice inside what it preaches outside? What of the way, for instance, negotiated intervention is practiced outside of but not between member states? And if the model that is projected onto the international scene is but an idealised version of what is an EUtopia, as argued earlier, consistency is all the more difficult between what happens inside the EU and what it does outside its borders.

But do others really or always prefer a consistent behaviour? Or more subtly what does consistency really mean - is it the same as sameness? Or does it require adaption underpinned by sensitivity to differences in circumstances and the preferences of others? We are back to the old question of whether the EU is sui generi, an $\mathrm{n}$ of 1 . Legal philosophy has long recognized that treating unequal actors equally is deeply unethical. Indeed, European integration happened in a unique historical and geopolitical context creating underlying conditions hardly replicable elsewhere: the states of Europe had just fought two devastating world wars, which deeply altered their conception of sovereignty and self-interest; the US provided a security umbrella due to the geopolitical constellations of the Cold War; and the longest phase of economic recovery and boom in the post-war era facilitated compromise and common decision-making. Conditions are different, elsewhere and at other times, especially in developing countries. Consistency between internal and external practices in EU action may therefore be counterproductive. It is thus problematic when the EU expects from third countries the same level of services liberalization or investment protection that it champions internally.

EU actors therefore ought to be sensitive to the context to which model practices are transferred. Such adaptation can occur along two dimensions. First, the width of adoption may be altered, depending on the context. Consistency between the inside and outside does not require the wholesale adoption of the EU model. We may conceive of the EU model as a toolbox of governance, from which individual elements can be authentically drawn, while others are simply deemed inappropriate in a different context. In short, we can think of the EU model as something that is 'disaggregatable'. Second, the specificity of EU models can be adapted to suit a specific domestic environment. Rather than transferring concrete trade standards or specific norms, EU actors can draw on general ideas and principles when engaging in EU model practices and think about how they may be implemented most profitably in a different context.

More broadly then, if international influence requires both power and legitimate social purpose, the question we must ask is when we should (generically) insist on shared universal purpose and when we should on the contrary uphold our own purpose and beliefs as a benchmark for other actors' behaviour. We are not necessarily moral relativists; but at the same time we need to avoid the kind of structural hypocrisy that is the hallmark of the imperial logic - that is, promoting one's standards in pursuit of our material interest 
while arguing that this is for the greater good or the other side's amelioration. Of course, that can also be the case, but not necessarily: the two must be distinguished. So, when it is in our interest to promote our standards, we need to state it as such. But if there is neither a moral nor a material imperative, we need to be adaptable and pragmatic. And we need to consider seriously the other side's standards, as stated earlier.

In sum, the consistency-sensitivity tension poses a challenge because the two guidelines for action are not implementable simultaneously when taken to their respective extremes. For one, consistency and sensitivity are opposites that can only be combined when tradeoffs are accepted or a situation for action is parcelled into small bits so that either one of the two concepts guides action in a specific case. In addition, strict sensitivity essentially requires the new formulation of a policy in each case that is particularly geared at suiting a local context. In such a situation, EU action falls into the realm of general foreign policy, leaving the sphere of EU model practices that we are concerned with here.

\subsection{The how question: Passive vs. proactive}

The most basic distinction relevant to the how question is whether the EU's influence is passive or active. This is clearly a spectrum, as with Manners' list, which ranges from contagion, cultural filter, to informational diffusion, procedural diffusion, overt diffusion and transference, where the last four are 'active' measures by the Union (Manners, 2002, 244245). These correspond to a gradation of tools or policy instruments, from least to most coercive: learning, socialisation or enmeshment; indirect support for actors abroad; provision of financial and technical support; coercive diplomacy and conditionality; sanctions and the use of forces.

Clearly, the former leaves greater room for agency and mutuality. European policy-makers, we believe, are usually not better suited than local actors to discern how the European experience may be adapted elsewhere. Local actors may use the EU as a source of inspiration in general or a more specific reference point, they might reject it or ignore it - it is their choice. Indeed, the EU has affected developments elsewhere by exerting impact "through what it is, rather than through what it does" (Maull, 2005, 778). Eduardo Duhalde, Mercosur's Head representative, for instance announced in regard to the founding of the 'South American Community of Nations' - a regional integration arrangement that combines Mercosur and the Andean Community -, that "our mirror will be the European Union, with all its institutions" (cited in Harris, 2005, 418). Except in fairy tales, mirrors do not talk back - and, in such a way, the EU has affected other integration schemes (see Lenz 2018).

However, local actors may explicitly ask EU actors for help, not only in supplying them with information about the EU, but also more specifically in the design and creation of policies or instruments. It is precisely because such demand-driven EU activism falls short of proactive promotion that it generally enjoys greater legitimacy.

But to the extent that the EU does act, we can find it acting in more or less coercive ways. Whether there are ever any legitimate grounds for the latter is surely a topic for intense debate. The fact of coercion itself is sometimes difficult to ascertain, as it ranges from open military imposition to much more subtle forms. Some associate the Gramscian concept of hegemony with coercion, despite the fact that it is based on the consent of the 'recipients' (Buckel \& Fischer-Lescano, 2009; Cox, 1983; Howson \& Smith, 2008; see also Diez, 2013). The direct military imposition of European models was characteristic of European colonial practices. Today, while such practices have been abandoned, memories still resonate 
strongly with political and civil society actors not only in parts of the world formerly colonized by European countries but also in many European countries themselves, from Ireland to Poland. It is especially against this background that we argue that the EU must be particularly careful today to avoid associations of coercion when engaging in its model practices.

While the worst forms of coercion have been abandoned by Europe, the EU still uses a wide range of measures to induce changes in behaviour outside its borders, from negative conditionality related to aid and trade to benign forms of influence through persuasion. The EU has been groping to find a form of positive conditionality faithful to this approach but with limited success. As a general rule, the less coercion the better but of course even some local actors might value being empowered by stronger forms of incentives. In short there may be a trade-off between legitimacy and effectiveness (Kleinfeld \& Nicolaïdis, 2009). Our view is that "empowerment strategies" may come closer to the spirit of mutuality that we espouse since they consist not in dictating one's standards to the other side but in helping out those among local actors who are most likely to promote practices compatible with the EU model. There is, of course, a highly interventionist and possibly paternalist connotation to picking the actors that ought to be empowered. Can we rescue the "rescue narrative" of yesteryears? Is the promotion of specified processes rather than substantive standards the best way to obtain legitimacy?

Ultimately, we need to take our analysis of the how to the structural level. We need to ask when a multilateral approach to devising and enforcing certain standards and practices is desirable and doable. And whether the "universality" of standards and practices that may legitimately constrain the action of states can ever be determined unilaterally, including by the gatekeepers of the "EU model."

\section{Conclusion}

In this paper, we have presented the building blocks of our critique of a discourse and a praxis, namely that of the EU as a model. Starting with semantics, we have suggested that the very term "model" may offer several meanings which in turn can serve as a heuristic for assessing the characteristics and legitimacy of the EU's model talk and its political translation. Loosely drawing on Hegelian dialectics, we proceeded by describing the thesis of the EU-as-a-model, as it is commonly related by European policy-makers and academics alike. We then contrasted this progressive narrative with the radical post-colonial critique that centers on member states' colonial histories. From these two poles, we developed a normative benchmark, emphasizing self-reflexivity and mutuality as key criteria, and assessed the EU's model practice in this light. Our main conclusion is that the idea of the EUas-a-model can be partially salvaged to the extent that the EU empowers its counterparts, both discursively and in practice, to adapt and appropriate the EU model to suit their own local contexts. 


\section{References}

Alter, K. \& Helfer, L. (2010). Nature or nurture? Judicial lawmaking in the European Court of Justice and the Andean Tribunal of Justice. International Organization, 64(4), 563-592.

Amin, S. (1989). Eurocentrism. London, UK: Zed Books.

Bechev, D. \& Nicolaïdis, K. (2010). From policy to polity: can the EU's special relations with its 'Neighbourhood' be decentred? Journal of Common Market Studies, 48(3), 475-500.

Beck, U. \& Grande, E. (2007). Cosmopolitan Europe. Cambridge, UK: Polity Press.

Behr, H. \& Stivachtis, Y. A. (Eds.). (2016). Revisiting the European Union as empire. Abingdon, UK: Routledge.

Bhambra, G. K. (2016). Whither Europe? Postcolonial versus neocolonial cosmopolitanism. Interventions: Journal of Postcolonial Studies, 18(2), 187-202.

Bicchi, F. (2006). 'Our size fits all': normative power Europe and the Mediterranean. Journal of European Public Policy, 13(2), 286-303.

Bickerton, C. (2011). European Union foreign policy: from effectiveness to functionality. Basingstoke, UK: Palgrave Macmillan.

Bohman, J. (2013). Kant, Madison and global democracy: republicanism and multilevel governance. In A. Niederberger \& P. Schink (Eds.), Republican Democracy: Liberty, Law and Politics (62-88). Edinburgh, UK: Edinburgh University Press.

Buckel, S. \& Fischer-Lescano, A. (2009). Gramsci reconsidered: hegemony in global law. Leiden Journal of International Law, 22(3), 437-454.

Buckel, S., Kannankulam, J., Wissel, J. \& Georgi, F. (2017). The European border regime in crisis: theory, methods and analyses in Critical European Studies. Berlin: Rosa Luxemburg Stiftung.

Bull, H. \& Watson, J. (1982). The expansion of international society. Oxford, UK: Oxford University Press.

Campbell, D. (2016). Poststructuralism. In T. Dunne, M. Kurki \& S. Smith (Eds.), International Relations Theories: Discipline and Diversity (203-228). Oxford, UK: Oxford University Press.

Chakrabarty, D. (1992). Postcoloniality and the artifice of history: who speaks for 'Indian' pasts? Representations, 37(Winter), 1-26.

Compact Oxford English Dictionary. (1991). Oxford: Clarendon Press.

Cowell, F. (2013). The death of the Southern African Development Community Tribunal's human rights jurisdiction. Human Rights Law Review, 13(1), 153-165.

Cox, R. (1983). Gramsci, hegemony and international relations: an essay in method. Millennium: Journal of International Studies, 12(2), 162-175. 
Dahrendorf, R. (1979). Europe: a model? In R. Dahrendorf (Ed.), A New World Order? Problems and Prospects of International Relations in the 1980s (35-52). Legon, Ghana: University of Ghana.

Diez, T. (1994). Europe's others and the return of geopolitics. Cambridge Review of International Affairs, 17(2), 319-335.

Diez, T. (1999). Speaking 'Europe': the politics of integration discourse. Journal of European Public Policy, 6(4), 598-613.

Diez, T. (2005). Constructing the self and changing others: reconsidering 'normative power Europe.' Millennium, 33(3), 613-636.

Diez, T. (2013). Normative power as hegemony. Cooperation and Conflict, 48(2), 194-210.

Duchêne, F. (1973). The European Community and the uncertainties of interdependence. In M. Kohnstamm \& W. Hager (Eds.), A Nation Writ Large? Foreign Policy Problems before the European Community (1-21). London, Basingstoke, UK: Macmillan.

Duchêne, F. (1994). Jean Monnet: the first statesman of interdependence. New York, NY, and London, UK: Norton.

European Social and Economic Committee. (2006). Opinion of the European Social and Economic Committee on social cohesion: fleshing out a European social model. Official Journal of the European Union, 16.12.2006, 2006/C 309/25, 119-125.

Farrell, M. (2005). EU external relations: exporting the EU model of governance? European Foreign Affairs Review, 10(4), 451-462.

Farrell, M. (2007). From EU model to external policy? Promoting regional integration in the rest of the world. In S. Meunier \& K. McNamara (Eds.), Making History: European Integration and Institutional Change at Fifty (299-316). Oxford, UK: Oxford University Press.

Fisher Onar, N. \& Nicolaïdis, K. (2013). The decentering agenda: Europe as a post-colonial power. Conflict and Cooperation, 48(2), 283-303.

Forsberg, T. (2011). Normative power Europe, once again: a conceptual analysis of an ideal type. Journal of Common Market Studies, 49(6), 1183-1204.

Grilli, E. R. (1993). The European Community and the developing countries. Cambridge, UK: Cambridge University Press.

Haas, E. B. (1958). The uniting of Europe: political, social, and economical forces, 19501957. Stanford, CA: Stanford University Press.

Habermas, J. \& Derridas, J. (2003). February 15, or what binds Europeans together: a plea for a common foreign policy, beginning in a core of Europe. Constellations, 10(3), 291-297.

Hansen, P. \& Jonsson, S. (2014). Another colonialism: Africa in the history of European integration. Journal of Historical Sociology, 27(3), 442-461.

Hansen, P. \& Jonsson, S. (2015). Eurafrica, the untold history of European integration and colonialism. London, UK: Bloomsbury Academic. 
Hansen, P. \& Jonsson, S. (2018). European integration as a colonial project. In O. U. Rutazibwa \& R. Shilliam (Eds.), Routledge Handbook of Postcolonial Politics (32-47). London, UK: Routledge.

Harris, R. (2005). Resistance and alternatives to Washington's agenda for the Americas: the prospects for regional versus hemispheric integration. Journal of Developing Societies, 21(3-4), 403-428.

Hartup, W. W. \& Coates, B. (1967). Imitation of a peer as a function of reinforcement from the peer group and rewardingness of the model. Child Development, 38(4), 1003-1016.

Hettne, B. \& Söderbaum, F. (2005). Civilian power or soft imperialism: the EU as a global actor and the role of interregionalism. European Foreign Affairs Review, 10(4), 535-552.

Hill, C. (1990). European foreign policy: power bloc, civilian power, or flop? In R. Rummel (Ed.), The Evolution of an International Actor: Western Europe's New Assertiveness (31-55). Boulder, CO: Westview.

Howson, R. \& Smith, K. (2008). Hegemony: studies in consensus and coercion. New York, NY, London, UK: Routledge.

Jones, E. (2006). Europe's market liberalization is a bad model for a global trade agenda. Journal of European Public Policy, 13(6), 943-957.

Kagan, R. (2003). Paradise and power: America and Europe in the new world order. London, UK: Atlantic.

Keohane, R. O. (2002). Ironies of sovereignty: the European Union and the United States. Journal of Common Market Studies, 40(4), 743-765.

Keukeleire, S. \& Lecocq, S. (2018). Operationalising the decentring agenda: analysing European foreign policy in a non-European and post-western world. Cooperation and Conflict, 53(2), 277-295.

Khanna, P. (2008). The second world: empires and influence in the new global order. New York, NY: Random House.

Kleinfeld, R. \& Nicolaïdis, K. (2009). Can a post-colonial power export the rule of law? Elements of a general framework. In G. Palombella \& N. Walker (Eds.), Relocating the Rule of Law (139-169). Oxford, UK: Hart.

Kojève, A. (1973). Kant. Paris: Wentworth Press.

Laffan, B. (1998). The European Union: a distinctive model of internationalization. Journal of European Public Policy, 5(2), 235-253.

Langan, M. (2016). The moral economy of EU association with Africa. London, UK: Routledge.

Langan, M. (2018). Neo-colonialism and the poverty of 'development' in Africa. New York, US: Palgrave Macmillan.

Langhammer, R. \& Hiemenz, U. (1990). Regional integration among developing countries: opportunities, obstacles and options. Tübingen: J.C.B. Mohr. 
Lavenex, S. \& Schimmelfennig, F. (Eds.). (2010). EU External Governance: Projecting EU Rules Beyond Membership. Abingdon, UK: Routledge.

Linklater, A. (2005). Dialogic politics and the civilising process. Review of International Studies, 31(1), 141-154.

Linklater, A. (2011). A European civilising process? In C. Hill and M. Smith (Eds.), International Relations and the European Union (435-457). Oxford, UK: Oxford University Press.

Lenz, T. (2012). Spurred emulation: the EU and regional integration in Mercosur and SADC. West European Politics, 35(1), 155-174.

Lenz, T. (2013). EU normative power and regionalism: ideational diffusion and its limits. Cooperation and Conflict, 48(2), 211-228.

Lenz, T. (2018). Frame diffusion and institutional choice in regional economic cooperation. International Theory, 10(1), 31-70.

Lenz, T. \& Burilkov, A. (2017). Institutional pioneers in world politics: regional institution building and the influence of the European Union. European Journal of International Relations, 23(3), 654-680.

Leonard, M. (2005). Why Europe will run the 21st century. London, UK: Fourth Estate.

Manners, I. (2002). Normative power Europe: a contradiction in terms? Journal of Common Market Studies, 40(2), 235-258.

Maull, H. (2005). Europe and the new balance of global order. International Affairs, 81(4), 775-799.

Maur, J.-C. (2005). Exporting Europe's trade policy. The World Economy, 28(11), 15651590.

McCormick, J. (2007). The European superpower. New York, NY: Macmillan International.

Meunier, S. \& Nicolaïdis, K. (2006). The European Union as a conflicted trade power. Journal of European Public Policy, 13, 906-925.

Miliband, D. (2007). Europe 2030: model power not superpower. Speech given at the College of Europe, Bruges, 15 November.

Monnet, J. (1978). Memoirs. London, UK: Collins.

Murphy, C. N. (2010). Lessons of a 'good' crisis: learning in, and from the Third World. Globalizations, 7(1-2), 203-215.

Nayak, M. \& Selbin, E. (2010). Decentering international relations. New York, NY: Zed Books.

Nicolaïdis, K. \& Howse, R. (2002). 'This is my EUtopia...': narrative as power. Journal of Common Market Studies, 40(4), 767-792. 
Nicolaïdis, K. (2004). The power of the superpowerless. In T. Lindberg (Ed.), Beyond Paradise and Power: Europe, America, and the Future of a Troubled Partnership (93-120). London, UK: Routledge.

Nicolaïdis, K. (2015). Southern barbarians? A post-colonial critique of EUniversalism. In K. Nicolaidis, B. Sebe \& G. Maas (Eds.), Echoes of Empire: Memory, Identity and Colonial Legacies (283-304). London, UK: IB Tauris.

Niranjana, T. (1992). Siting translation: history, post-structuralism, and the colonial context. Berkeley, CA: University of California Press.

Patten, C. (2003). 'The end of history' - the sequel. Cyril Foster Lecture delivered at the University of Oxford, 30 January.

Prodi, R. (2000). Europe and global governance. Speech given at the 2nd Comece Congress. Brussels, 31 March: SPEECH/00/115.

Roberts, C., Armijo, L. \& Katada, S. (2017). The BRICS and collective financial statecraft. Oxford, UK: Oxford University Press.

Ruggie, J. G. (1982). International regimes, transactions, and change: embedded liberalism in the postwar economic order. International Organization, 36(2), 379-415.

Sévon, G. (1996). Organizational imitation in identity transformation. In B. Czarniawska \& G. Sevón (Eds.), Translating Organizational Change (49-67). Berlin and New York, NY: Walter de Gruyter.

Sjursen, H. (2006). The EU as a 'normative' power: how can this be? Journal of European Public Policy, 13(2), 235-251.

Smith, K. E. (1998). The instruments of European Union foreign policy. In J. Zielonka (Ed.), Paradoxes of European Foreign Policy (67-85). The Hague, London, Boston: Kluwer Law International.

Spivak, G. (1996). Subaltern studies: deconstructing historiography? In D. Landry \& G. MacLean (Eds.), The Spivak Reader. London, UK: Routledge.

Staeger, U. (2016). Africa-EU relations and normative power Europe: a decolonial panAfrican critique. Journal of Common Market Studies, 54(4), 981-998.

Stein, J. \& Ahmed, A. (2007). The European Union as a model of international co-operation in science, technology and sustainable development. British Journal of Politics and International Relations, 9(4), 654-669.

Wæver, O. (1998). Insecurity, security, and asecurity in the West European non-war community. In E. Adler \& M. Barnett (Eds.), Security Communities (69-118). Cambridge: Cambridge University Press.

Walker, R. B. J. (1993). Inside/outside: international relations as political theory. Cambridge, UK: Cambridge University Press.

Weber, M. (1968). Gesammelte Aufsätze zur Wissenschaftslehre. 3rd edition, Tübingen: UTB. 
Weinhardt, C. \& Moerland, A. (2018). (Mis)perceptions in two- and three-level games: detachment in economic partnership agreement negotiations. Journal of Common Market Studies, 56(3), 576-593.

Wendt, A. (1999). Social theory of international politics. Cambridge, UK: Cambridge University Press.

Zaleski, S. \& Mittermayer, F. (2009). Exporting the European model of regional integration: the case of agriculture. In P. de Lombaerde \& M. Schulz (Eds.), The EU and World Regionalism: The Makability of Regions in the 21st Century (45-62). Aldershot: Ashgate.

Zielonka, J. (2008). Europe as a global actor: empire by example? International Affairs, $84(3), 471-484$. 